\title{
Current models of corporate social responsibility in Russia
}

\author{
Elena R. Schislyaeva ${ }^{1}$ \\ Olga A. Saichenko ${ }^{2}$ \\ Olga V. Mirolybova ${ }^{3}$
}

Recibido: 13 de marzo de 2013

Aprobado: 15 de junio de 2013

\begin{abstract}
Schislyaeva, E, R., Saichenko O. A. \& Mirolybova O. V. (2013). Current models of corporate social responsibility in Russia.
\end{abstract} Activos 21, 19-40

Clasificación JEL: M14 - M19

\begin{abstract}
Corporate Social Responsibility (CSR) is a central element in the management of organizations in all countries of the world. The paper reviews the main trends in the management of CSR in Russia, where the transition to capitalism generated a serie of social tensions.

The text makes a statement of the main components that make and integrate CSR programs and their scope in post-Soviet Russia.

1 Doctor of science in economics. Professor. Head of the department International Graduate School of Management, Engineering-Economic Institute, Saint-Petersburg State Polytechnic University. Tel: 8 (812)-329-47-94. E-mail: dean@igms.info

$2 \mathrm{PhD}$. Associate professor of the Department «International Business» International Graduate School of Management, Engineering-Economic Institute, Saint-Petersburg State Polytechnic University. Tel: 8 (812)-290-99-94. E-mail: dean-office@igms.info $3 \mathrm{PhD}$. Associate professor of the Department «International Business» International Graduate School of Management, Engineering-Economic Institute, Saint-Petersburg State Polytechnic University. Tel: 8 (812)-329-47-96. E-mail: olga.v.mir@gmail.com
\end{abstract}




\section{Keywords}

Social Policy, Social Responsibility, Administration, Government, business strategies.

Schislyaeva, E, R., Saichenko O. A. \& Mirolybova O. V. (2013). Modelos actuales de Responsabilidad social corporativa en Russia. Activos 21, 19-40

\section{Resumen}

La responsabilidad social empresarial (RSE) es un elemento central en la gestión de las organizaciones en todos los países del mundo. El documento revisa las principales tendencias en la gestión de la RSE en Rusia, donde la transición al capitalismo generó una serie enorme de tensiones sociales.

El texto hace una exposición de los componentes primordiales que integran los programas de RSE y sus alcances en la Rusia pos-soviética.

\section{Palabras clave}

Políticas sociales, responsabilidad social, administración, gobierno, estrategias empresariales. 
Schislyaeva, E, R., Saichenko O. A. \& Mirolybova O. V. (2013). Modèles actuels de Responsabilité Sociale Corporative en Russie. Activos 21, 19-40

\section{Résumé}

La responsabilité sociale d'entreprise (RSE) est un élément essentiel, dans la gestion des organisations dans tous les pays du monde. Le document revoit les principales tendances dans la gestion de la RSE en Russie, où la transition au capitalisme a produit une série dénormes tensions sociales.

Le texte fait une exposition des composantes primordiales qui intègrent les programmes de RSE et sa portée dans la Russie post-soviétique.

\section{Mots clés}

Politiques sociales, responsabilité sociale, administration, gouvernement, stratégies d'entreprise. 


\section{Introduction}

Corporate social responsibility is in the focus of attention due to the necessity of finding the ways to harmonize the relationship between business, government and society, but the reasons behind this interest in Russia and in the West are different. In developed countries corporate social responsibility (CSR) came as a response to social contradictions which are seen by the large part of the world community to have been caused by the activities of transnational corporations. Social responsibility was aimed to alleviate these contradictions and raise the prestige of public business. In Russia the request for "social responsibility" was formulated by the State at the beginning of the new century. As seen by the Russian government social responsibility should be a kind of "payoff" for privatization, during which the state property was given to new owners for a song. As the tension between top businesses and the state has become strained in Russia, social responsibility is now regarded by many members of the highest strata of business as "a strategy of adaptation" to the new political situation.

Turning to positive experience of corporate social responsibility, we should mention some large multinational companies including those operating in Russia as well as Russian businesses having assets abroad. Such companies are responsible not only for dealing with their own internal social problems. The boundaries of social responsibility of large companies are much wider, and their activities may include solving problems of the national importance, such as reducing poverty, increasing the competitiveness of the country, fighting against terrorism.

But why does business have to be involved? Businesses are mainly concerned with making profits which also ensues more jobs, wealthier society, greater GDP and higher country's competitiveness. But businesses can not be isolated from the society -they are integrated into the system of mutual expectations which makes mere profit making quite a hard task: corporations are to meet the expectations of stakeholders- government, 
shareholders, customers, local communities, partners, investors, and others.

Russia is now making first steps towards the social responsibility of Russian businesses. Russian studies reveal a number of special features related to CSR. In the focus of the study in the first place there are large companies, whose management is keen to convey information about the social responsibility of their business. Second, there is virtually no information about the social responsibility of small and medium businesses. Third, the researchers often tend to "impose" schemes of analysis accepted in the West onto the post-Soviet reality. Fourth, and most important, social responsibility of the business is considered by many Russian analysts as a response to the "request" formulated by the State. Even if this view of the problem reflects the realities, it restricts the scope of research: it does not focus on the mechanisms evolving companies into social projects but it focuses on the policies of the state instead.

Corporate social responsibility of any company is based on its social policy. Social policy of the company can be divided into internal and external.

Internal social policy (SP) of the company is directed to its employees. It has to be implemented by senior managers of the company and its trade unions. The administrative economy was dominated by the companies which performed a wide range of functions. The company itself was to a large extent a kind of social security for its workers. In 1980s 32 million Soviet citizens lived in the apartments at the expense of enterprises, 30 million employees enjoyed medical facilities (clinics, recreation centres) owned by enterprises, 1.5 million children each year used to spend their holidays in children's recreation camps owned by enterprises. According to Russian sociologists L. Gordon and E.Klopova, in such collectivist society the company was a kind of "the social community".

Since the beginning of market reforms corporate social policy has gone through the period radical changes. Major changes have affected 
social infrastructure of the companies. There are three stages of these changes: the reduction of social infrastructure, its stabilization and optimization.

In the first stage (early and mid 90's) there was a sharp decline in social infrastructure of the businesses. During these years, leaders of all kinds of enterprises reduced "social programs" enormously, trying to get rid of non-core assets. In just a decade of the reforms, two-thirds of social facilities owned by enterprises were given to municipal government. This process was spontaneous and uncontrollable. On the way out of the crisis and the improvement of the financial state of enterprises the reduction of social programs was no longer regarded by management as a condition of survival in the market economy. In the second stage (1997/1998-2000) there was a stabilization of social infrastructure, and the attitude to social facilities changed for the better. Since the beginning of economic recovery (2000-2001) and the transition of enterprises from survival to development some of them started to optimize their social infrastructure.

Most managers and business proprietors who participated in the study claimed that their companies perform some social functions. The analysis of the interview demonstrates what strategies and priorities are chosen by the management and what social policies are targeted. There are three types of strategies applied by Russian companies: 1) the strategy of social compensation package, 2) the strategy of social infrastructure support, and 3) a mixed strategy that combines preservation of social infrastructure and partial monetization of social benefits.

According to the research quite a small number of managers and business proprietors stick to the strategy of social compensation package (just 15\% from the number of respondents). This is a marketing strategy involving the provision to the employee along with the salary of so-called social package which is supposed to cover the expenses on vacation, medical treatment, vouchers to children's recreational camps. This social compensation package may be quite small and may vary according to an 
employee position. But it should be noted that it frees managers from the necessity to maintain social infrastructure and provide social services directly at the enterprise.

Analyzing social policies of post-Soviet leaders, Prokhorov, the analyst from the Russian city of Yaroslavl, formulated his own concept of "Russian model of governance". The researcher is convinced that in market conditions the entrepreneurs introduce a system of "serfdom" to keep their personnel on. Low wages coupled with strong social benefits is one of the forms of such "serfdom". At small companies this system is used by default, at large enterprises it is enshrined in collective agreements.

The strategy to support social infrastructure is applied by a quarter of managers and executives interviewed for the study, including those working at the state enterprise of the defense complex "Spark". In the early 90s it eliminated nearly all social programs, but in 2000-2001 there came the decision to re-establish them. Today the company owns one of the best recreational centers in Perm, sports facilities center and a recreational camp for children. The federal budget annually allocates 30-40 million rubles to maintain this social infrastructure. However, the supporters of this infrastructure at the enterprise admit it becomes increasingly difficult to maintain this strategy due to high costs and the intention of the company proprietors to reduce non-core expenses. The heads of such socially responsible companies are constantly under pressure "from below" and "from above": workers call for maintaining social infrastructure, and company owners demand its reduction.

A mixed strategy combining social infrastructure support and partial monetization of social benefits seems to be the most popular strategy now - more than half of the respondents find it most attractive. Among the reasons due to which the transition to monetization of social services and other forms of market economy is not always possible managers and company owners quote the following: 
- Impossibility to pass over social infrastructure to municipal government due to the lack of funds for the maintenance of social infrastructure;

- Failure to market objects of social infrastructure;

- Administrative opposition by the city administration to the transfer of the social infrastructure of enterprises;

- Traditions found in the workforce, and high demands of workers for the social services provided by the enterprises.

The popularity of the mixed strategy is attributed by the respondents to the transitional period in the society and to its unwillingness to accept a new market philosophy overnight. Even the most consistent liberals, who participated in the survey, believe that the incompletion of the transition period makes it impossible to implement liberal scenario in its classical form in Russia. "The question as to which way we should move is too difficult. In the West social policy includes a package of social compensation. We are a transitional type and we can not just follow western ways", - says the director and owner of the company. It is worth mentioning though that some leaders of Russian enterprises oversimplify western experience which they often associate with the American model of capitalism.

Prospects of mixed strategy development at enterprises are quite vague, particularly due to individualistic attitudes of the new generation of workers, their eagerness to earn high wages quickly and their indifferent attitude to social services available at the enterprise. Similar changes are taking place in management. There is a tendency for high positions in the companies to be taken by young managers. "Young Wolves", as they are called by the more experienced managers, are focused on solving economic problems, many of them being graduates of Western business schools, and paternalism in any form is strange to them. Such managers stick to the principles of pragmatism and stiffness. 
There are three dominant types among the leaders of Russian enterprises: consistent opponents of social policies, rational paternalists and compelled supporters of social policies. Consistent opponents of social policies make up the smallest group. Its members advocate a liberal way of development, following the classical formulation of M. Friedman, according to which "the only goal of business is to maximize profits within the framework of the given rules of the game." Representatives of the second type - rational paternalists - believe that social policy of the company, though being quite expensive, enables you to maintain the traditions and image of the company, cope with social unrest, manage workforce, and may even bring certain economic benefits.

So called compelled supporters of social policies form the largest group. Its members believe that current social policy, though being quite expensive, enables to retain and motivate staff, develop the company, and helps to reduce costs due to employees' sick leaves. Most of the compelled supporters of social policies are convinced that their choice of this strategy is a temporary solution for the lifespan of the generation born the Soviet era.

The priorities of the internal social policy introduced by the company are centered around educational programs and reproduction of labor force. Projects targeted to support the retirees and employees' children are of less importance although they are also taken into consideration by the management.

The key value in many companies is attributed to educational projects which are considered by the management to be an important prerequisite for restructuring and modernization of production as well as the contribution to "human capital." Further professional training organized at some enterprises can be seen as a response to the collapse of the Soviet system of engineering education. Educational programs are all the more relevant due to the fact that the majority of Russian enterprises are faced up with the problem of staff aging and the lack of well-trained and efficient workers. 
Companies facing the problems of labor force tend to develop programs with the involvement of young people. A significant role in internal social policies is given to sports, health care and disease prevention. Some enterprises such as JSC "Mineral Fertilizers" (Perm), JSC "Yaroslavl Engine Plant", JSC "Kotlas Pulp and Paper Mill (Korjazhma)" implement largescale children's projects. Others provide financial support to their retirees. However, it should be noted that these projects do not typically involve over-expenses and are implemented in compliance with the financial capacities of the enterprise.

Internal policy of the enterprise is often formalized. Social issues are fixed in labor agreements concluded between unions and management. Nowadays there are collective agreements in most major Russian companies. They stipulate working conditions and employees' salaries, social benefits and insurance arrangements for the staff and in some cases for their family members and retirees. Collective agreements make internal social policy of the company public and transparent. There is also an implicit social policy aimed at encouragement and promotion of top managers and company experts implying special incentives and perks. On the one hand, this policy creates "special conditions" for top managers and company experts, on the other hand, it builds a system of dependence depriving highly skilled personnel of their freedom. At present investments into internal social policies take the centrepiece in the social investments of Russian companies. According to the Association of managers, large Russian companies spend up to $60 \%$ of the social budget on staff development.

Internal social policy of Russian companies has the following characteristics. First of all it can vary according to the company's rules. Each company chooses the priorities of the internal social policy and mechanisms for its implementation. The type of internal social policy depends on the level of "advancement" of its market strategy. The incompletion of structural reforms aggravates the differentiation of internal social policies: so far most companies have failed to establish uniform rules for 
all their affiliated companies, and each of them creates the social policy it can afford.

Secondly, the internal social policy is determined by senior management and trade unions (if there are unions at the enterprise). In determining the priorities of internal social policy it is not the needs and demands of the staff of the company which are particularly important, but the senior management decisions. Trade unions do not yet play a significant role in the development of the internal social policy. They fail to take control over the business. They are mainly involved in solving their own internal problems and are still learning to use the resources acquired in the post-Soviet era (i.e., to negotiate and conclude collective agreements, to file lawsuits, etc).

Thirdly, the internal social policy of the company can not be influenced by any regional or local authorities. However, some influential mechanisms on part of the authorities still remain: so, they can, for example, slow down or speed up the "reduction" of the company's social programs, or they can put some pressure on the head of the company to keep the excessive labour force.

External social policy is aimed at the social environment of the enterprise, i.e., the neighbourhood, the community, the city, the society as a whole. It aims to create favorable conditions for business development and to harmonize the relationship between the enterprise and the environment. The most important function of external social policy is the facilitation of positive business relationships with the authorities, both regional and local.

In Soviet times enterprises were active to carry out their external social policy. The researcher from France, A.Yegorova-Comte came to the conclusion that since 1960s the relationship "enterprise-city" has changed dramatically. Enterprises have turned into a leading force in urban development because they had their own economic and financial resources. In 1960-80s of the last century the Soviet Union brought to life the idea of 
the socialist city built around the company and providing the services the company needs.

The largest and most successful companies are very sensitive to public opinion. Up to date many Russian companies have realized the effectiveness of the systemized social policy. Some of them spend around $17 \%$ of their profits on social programs. Among socially responsible companies there are such leaders as a group of SUAL, MMC "Norilsk Nickel", JSC "Lukoil”, JSC "Severstal" which have adopted the code of corporate governance and started to publish reports on their social activities.

It soon became obvious that assistance to vulnerable groups of veterans and the disabled is not one of the main issues on the public agenda today even though regarded as important and notable. According to international standards of the concept of social responsibility the entrepreneur today is supposed to feel equal responsibility as the business partner, taxpayer, employer and benefactor. Recent polls conducted by the Association of Managers show that consumers, first of all, expect from the entrepreneur a quality product at a reasonable price, and value square dealing in his code of business behavior rather than his supporting arts, although charity actions to help orphans and participation in solving other social issues deserve much respect.

There are different criteria to evaluate the performance of corporate social responsibility models. One of the criteria is, first of all, their effect on the main goal of business development. While capitalization is one of the most important criteria in international practice, in Russia it is the creation of political conditions favourable for running and developing businesses. While solving these problems it is extremely important to meet the expectations of society. At present we need the strategic alliance of business and society as creative and robust powers which, though, may have some claims against each other. Therefore, the second criterion of effective corporate social responsibility is the growing confidence in the company and strengthening its positions. 
Effective implementation of CSR models combine practical results and broad participation in dealing with social problems. For example, one of the companies made large contribution into the regional budget for the construction of social facilities and covering debts on child allowances. Another company held a competition of social projects whose final results were summed up by local television online popular vote. As a result the second company received wider coverage and greater confidence than the first one, and this growth of confidence is very important in terms of effective corporate social responsibility.

Participation models of Russian companies in solving social problems can be divided into two groups: models of social investment and communication models. First group requires significant financial investments by the company. Social investments can be allocated to support contests and competitions, community funds, scholarship programs targeted to the future of the country's strategic development.

Models of the second group focus on the rapport with stakeholders, and can be implemented at much lower costs compared to the first group of models. Among mechanisms used in communication models there are coordination boards for social partnership as platforms for the dialogue with local authorities. They are also involved in environmental and socioeconomic impact assessment as well as external audits (this activity is not yet widespread in Russia with the exception of the Sakhalin region development where it is quite intensive).

The most significant forms of external social policy are the following: maintenance of social infrastructure, charity and participation in major social projects. Most often social infrastructure is supported by townforming enterprises. They not only provide jobs, but also the supply towns with electricity, water, heat, communications. For example, Kotlas Pulp and Paper Mill in Korjazhma [19] along with maintaining housing complex, builds city hospital with all modern facilities, sponsors large cultural projects, finances maintenance and renovation of sports and recreational facilities. In 2003 the enterprise allocated more than 36 
million rubles for these purposes. At present, the enterprise intends to "pull out" of the social sphere of the city gradually in order not to provoke a citywide crisis. To this end, the company has been gradually reducing the financing of urban institutions (schools), though it is still funding all preschools. Given the importance of core town-forming enterprises to the economy (there are 466 plants in Russia), we can assume that they bear the huge social burden.

Most companies restrict their participation in external social policy to charity events. They include actions aimed at assisting the development of a particular social group, or providing some social support. Main objects are charitable educational institutions, institutions of culture, health, sports, science, as well as confessional organizations. The disabled, orphans, children and retirees are first priority target groups. Nowadays, large companies tend to shift from single charity events to wide-scale involvement in social policies of the region (or the city). This is due to several factors. First of all, charitable activity does not meet the demands of businesses by many parameters. Among the weak points of charitable activity business representatives quote: spontaneity, inefficiency, lack of consistency, failure to monitor the expenditures, subjectivism. Secondly, in the period of transition from the stage of survival to the stage of development there is a need for thorough planning of expenses, which is not possible without a systematic approach.

The transition from charity to systematic social policy is implemented in a variety of forms. There may be large social projects carried out by businesses together with the regional or municipal authorities. In Yaroslavl region one of such projects resulted in the construction of the largest sports facilities centre - Ice Palace. The project was initiated by the regional governor. Large Russian corporations and local businesses, together with the regional budget, allocated their funds to participate in the project. The construction of ski slopes and the sports facilities center in Rybinsk for professional athletes is another example of wide-scale social projects. 
Organizing tenders for social and cultural projects is another form of systematic external social policy of the enterprise.

Tender is a public invitation for external contractors to submit their bids in accordance with the set of stated criteria. Best applications are funded, projects results are summed up. At the opening ceremony of the first tender for social partnership at the fair in the town of Perm, it was called a strategic tool for innovation management. Forms of tender management include administering external organizations, special departments inside the company with the assistance of consultants, as well as corporate and private foundations.

In 2002 JSC "Lukoil-PERMNEFT" (Perm region) invited tenders for social and cultural projects for the first time and the winners received grants to implement their plans. Over the years, tenders were declared in different categories: environment, sports, historical and cultural traditions, healthcare and education. In setting priorities, the company "Lukoil" works closely with the regional and municipal authorities. In 2002 there were 12 priorities put forward, in 2003-2004 the number of priorities was reduced, though the number of participants increased. Both physical and legal entities were able to participate in the tender. One of its goals is the development and support of small businesses. Over the years total grant funding has increased enormously: in 2002 it amounted to 2 million rubles, in 2003 - 4 million rubles, in 2004 - 10 million rubles, with one grant amounting to 150 thousand rubles. The company "Lukoil" intends to develop tendering policy in the future. At the initiative of the company there is a training course of social project planning in the Perm region.

In 2003, first tender for social projects was organized by "Permregiongas", the regional structure of "Gazprom". It took place in four districts of Perm region, where the company has its branches. In 2003, total grant funding was less than $1 \mathrm{mln}$ rubles, with one grant amounting to an average of about 100 thousand rubles. In the future the company plans to expand its activities and hold tenders in other districts of Perm region. 
Tenders bring about a new type of relationship between the corporation and the community. It is characterized by openness and publicity (which draws the attention of the regional community); targeted social support; the creation of permanent sites for the interaction between government, business community and civil institutions; the formation of the civic stance; initiatives support coming "from below." Carrying out major social projects enables to create a positive image of the company and gives its management the possibility to get political dividends from the external social policy. Many of the interviewed managers and company proprietors were elected deputies of regional legislative or municipal representative bodies.

There are other examples of tenders:

- Tenders for social projects;

- Tenders aimed to support small businesses, with both grant schemes and loan repayment schemes;

- Tenders for municipalities aimed at repair and reconstruction, development of heat and water supply for schools, hospitals, etc.

Companies apply two forms of administration: they transfer management of finances to external funds and draw consultants to the process of organizing their activities.

Tenders among small businesses and municipalities are held quite infrequently. Their main goal is to create a production chain, to support services related to the activities of the company, and, what is most important, to improve business climate in the local community. Thus, the mission is to reach economic stability in Russia through the support of small businesses. The program stipulated the issuance of loans on terms of repayment, and the support and development of business incubators under grant funding. The "Eurasia" fund has wide experience of supporting small business in Russia and very often takes on the functions of the administrator of such 
tenders. Support of small business leads to diversification of the municipal budget, since it evolves new taxpayers and improves business environment in the region.

There were ten winners in the tender for social infrastructure development projects of Samara region municipalities, and total grant funding amounted to 65 million rubles. These were projects of modernization of education and health facilities, systems, utilities and transport. As usual, this involved reconstruction of heat supply system, installation of a new boiler, modernization of water purification system (oil-industry workers are well aware of the importance of water quality for the activity of the company), modernization of hospitals, schools, etc. However, the fact that the municipality workers for the first time in their life wrote a funding request was something new. The feasibility study with the formulas took five pages and enlisted both capital and operating costs. The decision was made on the basis of economic criteria, and in the course of the competition many municipalities abandoned their ideas. Unlike the tenders administered by CAF and "Eurasia", it was the host company that made the final decision, determined grant funding, and signed the contract. Methodological support was provided by the Foundation "The Urban Institute" which trained employees through the complex procedure of expert assessments to draw ratings for the company to take a proper decision.

Along with organizing tenders businesses are also engaged in the introduction of "social management." Large companies work in cooperation with the administration of the territories of town-forming enterprises, with the aim of establishing municipal services and training municipal officials. Companies conduct trainings and seminars for local authorities, invite experts and consultants to train local leaders to use budget funds effectively. Educational programs are of great importance, as the professional level of municipal employees especially in little towns is quite low. Many respondents noted that the introduction of "social management" leads to positive results, budgetary savings being most important. 
Local community foundations make up another model. When CAF only appeared in Russia in 1990s, one of the major issues related to CSR was: "Will businesses invest into this foundation?" It seemed much more efficient to give money directly to charity rather to some foundation where it may be lost. But Russian experience confirmed the international practice - acting through the foundation turned out to be profitable. Community foundations raise money on a limited area from different sources, primarily, from businesses of all sizes. Community foundations operate on the basis of transparency and gradually build up their capital, with the view of earning interest in the future. The experience of Togliatti foundation is often given as an example of successful implementation of this model. It turned out that the donations from entrepreneurs made in the framework of a public foundation are much more efficient. Winners' brand "Sponsor of the Year" became prestigious for the companies - winners of the title and important for the business environment of the city. It also triggered the principle of co-branding and broad social participation, which enabled the companies to get a lot more gain on the investment.

\section{Scholarship programs}

These models became widespread in Russia not long ago. Experts explain their appearance by expanding business strategic planning, the need to manage human resources and staff. Therefore a number of scholarship programs are aimed at employing and developing staff. For a long period of time Russian educational institutions have supported talented students. The Federal scholarship program of V. Potanin's Charity Foundation has become the first successful initiative, which is external to the university management, to mark such a direction as an important public priority. Another textbook example of the support for students and young researchers is grant programs of D. Zimin's Private Foundation "Dynasty", aimed at the development of science, support of talented school graduates. In 2004 such grant programs covered 40 universities in 16 Russian cities. The financial support of this foundation allows young researchers to form working teams and small innovative businesses able to enter the market 
with scientific ideas and science-based commercial products. For a long period of time the support of students and teaching staff has been provided by the Lukoil Charity Foundation. Talented diligent students, who succeed in studies and public activity, are awarded small grants not only by private and corporate foundations, but a number of companies (e.g. computer supermarket NICS, established by graduates of the Physical and Technical Research Institute). Wishing to help their alma mater, the graduates started paying individual scholarships to students and offer them part-time jobs during summer holidays. It was a good HR method: the company could benefit from the students with job experience in this very company.

There are also other examples: Scholarship program of the CreditMoscow Bank for graduate students of economic departments in Moscow universities. The students are granted a bank card, which is the first step for the bank to find a future customer in the elite environment, because the best students can become entrepreneurs, managers etc.

Scholarship programs can affect the expansion of the company market. Kaufman's Charity Foundation was established by M.A. Kaufman, Whitehall company president, premium wine dealer in Russia. The company faced a problem - Russian people do not have wine-drinking culture. Representatives of the company decided to educate not only sales-assistants, but other stakeholders via grant training programs in Burgundy for graduate students-economists and student -journalists.

\section{Strategic investments}

This implies partnership programs with governmental and public institutions aimed at great changes in the social cultural environment. Such programs include long-term large-scaled events in the areas of education, culture, politics etc. The main example of such programs is the program "Internet Learning Federation" of the Open Russia Foundation. This program is of an unprecedented great scale: it covers 41 regional centres, 90 
000 teaching staff. By 2005 the number of centres will have increased to 50 and the number of teachers to improve the qualification through further training will have risen to over 50000 annually. The program is implemented in the effective partnership with governmental institutions within the framework of the Ministry of Education goal-oriented program of developing the educational and information environment. In October 2003 the team of the "Internet Learning Federation" was awarded for the educational work by the President of the Russian Federation. This contributes greatly to the intellectual potential of Russia and solution to national problems.

Communicative models of the Russian company participation in tackling social problems. Social reporting in Russia is still perceived as a "break" in the main activity, but nowadays the attitude to social reports is changing, and companies, dealing with them, seriously negotiate with counterparts. The company "BAT Russia" is the first in the country to launch social reporting. The first stage of reporting comprises negotiations and meeting between company representatives and counterparts with the participation of external facilitators. Among the activities are making claims, declaring relevant expectations to the company. Later such a plan is analysed from the point of representation, objectivity, importance. Every participant receives the reply with the list of company obligations. At the second stage the obligations are claimed to stakeholders, in a year the social report has to comprise not only promises, but their implementations. However, not all the companies follow such a process, therefore the experience of "BAT Russia" in this area is quite positive. They have launched the mechanism of responsibility for their promises.

Social reporting has become a widespread tool in the business community. Hence the Russian Union of Industrialists and Entrepreneurs has approved of profound studying the reporting standards and putting them into practice. A less known model is the one of environmental and social influence. The study of the environmental and social influence was carried out by the company "Sakhalin Energy" within the framework of the program "Sakhalin - 2". Following the principles of social responsibility, the 
company conducted the survey, analysed all possible influence of a new mineral deposit on the social environment, on the one hand, and landscape, bio-variety, cultural and archeological heritage, on the other hand. The company conducted meetings with the local community seeking answers to the questions: What would happen to the indigenous people? How could the major oil company affect the resource access and allocation? How would it influence the jobs? Would Sakhalin residents face discrimination on behalf of migrating high-quality specialists? The results of the abovementioned meetings were stated in the document "Assessment of Influence on the Environment and Social Sphere". The total expenditure per person for the manufacture of this product amounted to 30 person - years. However, this survey helped the company to avoid a lot of mistakes made during the implementation of the project.

Representatives of other Russian companies working on Sakhalin defined this method as useful and progressive. They hoped to apply it in future.

Any social project tends to be initiated by the government. The decision to join a major social project is made by the company owner taking into account company productivity and political targets. If the government applies to the CEO of the company, the latter submits the reasoning of the social project and budget value to the owner. If a company is integrated into the regional space, its external policy is systematic and long-term, the company management and regional authorities sign agreements. However, in Russia it is very often that the agreements "business - government" are informal, and social projects are introduced after private agreements between top managers.

The main coordinator of social projects in Russian regions is government. But recent time, companies' own social projects have also gained popularity. The civil society in Russia is not an equal partner of business and government, it can not form the demand for the social activity.

Russia still does not have a common model of social responsibility, which leads to a great variety of social activity in companies. Every Russian 
company is seeking its own balance between the economic effectiveness and social responsibility. The forms and techniques of social responsibility in Russian companies are determined by personal preferences and interests of managers and owners.

The "personification" of social responsibility fits in the post-privatization situation when the role of managers in decision-making has increased significantly. Moreover, Russia suffers a big gap between the community and business on account of social responsibility priorities. This gap exists until the community starts to express openly their own interests.

Involvement of Russian companies into the social activity is occasional. A great social burden is laid on city-forming companies. Most socially responsible companies are in such industries as oil, gas, metallurgy and chemical one. These industries are ready to invest great funds into the territory development, because their production is environmentally hazardous. The least social responsibility is shown by managers and owners of post-Soviet companies without their own history and traditions. Most managers of the companies set up in the Soviet Time are not opponents of the social policy, but critics of its today's forms.

Participation of companies in the social policy is influenced by many factors: welfare, strategy of development, company history and traditions, integration into the regional life and importance of the region in the company strategy. No wonder, most socially responsible companies are regional ones, integrated into the local community, and major Russian companies for whom the region is essential.

Russian companies are unique because they are in between the Soviet past and Market present. In such conditions social responsibility is an adaptation mechanism which allows the former Soviet enterprises to adapt their performance to the market situation. The exception is major Russian companies trying to adopt new international principles and standards of socially responsible business. 